\title{
The Mediating Role of the Sense of Relatedness and Task Cohesion in the Relation between Psychological Power Distance and Efficicency of a Working Team
}

\author{
Laurent Auzoult \\ Department HSE, University of Franche-Comté, Besançon, France \\ Email: laurent.auzoult@univ-fcomte.fr
}

Received August 13 $3^{\text {th }}, 2013$; revised September 12 $2^{\text {th }}, 2013$; accepted September $29^{\text {th }}, 2013$

\begin{abstract}
Copyright (C) 2013 Laurent Auzoult. This is an open access article distributed under the Creative Commons Attribution License, which permits unrestricted use, distribution, and reproduction in any medium, provided the original work is properly cited.
\end{abstract}

\begin{abstract}
Understanding of the effectiveness of work-teams is a major issue in the business world, where they are expected to facilitate developing individual skills and increasing organizations' efficiency. Eighty-three engineers working in teams have responded to a questionnaire devised to measure perceptual power distances, the sense of relatedness, cohesion measured by integration around the task, and teams' effectiveness. Results reveal that "task cohesion" and sense of relatedness mediate the relationship between power distance and perceived effectiveness. These results are related with those observed in the context of the self-determination theory and presented in order to highlight their practical implications.
\end{abstract}

Keywords: Power Distance; Team Effectiveness; Self-Determination Theory; Autonomy

\section{Introduction}

Along with potency (Jordan, Feild \& Armenakis, 2002), cohesion is presented as a key determinant of work-teams' effectiveness (Evans \& Dion, 1991; Cohen \& Bailey, 1997; Webber \& Donahue, 2001), though this psychological construct does not always turn out to be as unambiguous as one would like (Friedkin, 2004). Initially, cohesion reflects all forces encouraging a group's members to stick together (Festinger, 1950). Cohesion has gradually been broken up into several dimensions that refer to interpersonal attractiveness and individual or collective commitment to the task. "Task cohesion" seems to be a better predictor of effectiveness than social cohesion (Mullen \& Cooper, 1994).

"Task cohesion" refers to team-members' perceived spirit of unity around the activity, i.e. to the quality of cooperation within the team. Cooperation quality could account for a sense of relatedness (Lavigne, Vallerand, \& Crevier-Braud, 2011), which reflects a sense of acceptance, i.e. the feeling of being understood and accepted by others, as well as a sense of intimacy, i.e. feeling one is emotionally attached to colleagues. As regards running a work-team, we can assume that the stronger the sense of relatedness among teammates (i.e. their feeling close to - and understood by - others), the more satisfactory the perceived quality of cooperation. A study by Deardorff Bell and Belohlav (2011) highlights the impact of relationships quality (sharing ideas and communications quality) on performance. In this case, cohesion might be expected to mediate the relationship between the sense of relatedness and perceptions about the team's effectiveness.

From a broader perspective, cohesion mediates the effects of psychosocial factors referring to the team's organizational environment (Gladstein, 1984), the quality of individual interac- tions (Mesmer-Magnus \& DeChurch, 2009) or to wage-earners' characteristic features (Campion, Papper \& Medsker, 1996). Sharing common values has been put forward to account for work-teams' effectiveness (Ashkanasy \& O'Connor, 1997; Stinglhamber, Bentein, \& Vandenberghe, 2004). Schaubroeck, Lam and Cha (2007) and Earley (1999) have shown a relationship between power distance values, which refer to the degree of inequality employees consider as normal (Hofstede, 2001), and work-teams' performance. Specifically, it has been shown that the higher power-distance values are (i.e. when employees consider inequality as normal), the better the team's performance turns out to be. Power distances may also be considered as psychological distances (Mulder, 1977), i.e. a degree of perceived inequality within a power structure. Psychological distances are related with psychological values. In this case, the more individuals can express strong power values, the closer to their line manager they perceptually get, while distancing themselves from the organization's shop floor (Auzoult, 2012). As for psychological power distances vis-à-vis the team leader, reducing psychological power distances should increase the team's perceived effectiveness.

The power equalization effect, i.e. the relation between performance and reduction of status and power, has already been highlight at organizational level (Abdel-Halim, 1980) but never in work team level. In this study, we examine the mediating role of a sense of relatedness and cohesion between power distance and work-teams' effectiveness. We rely on observations made about training engineers working in teams on industrial projects. Studies involving teams during training-periods highlight processes similar to those seen in professional or sports organizations (Lent, Schmidt, \& Schmidt, 2006; Hsu, Ya-Ling Chen, Chiu, \& Ju, 2007; Lira, Ripoll, Peiró, \& González, 2007). 
We expect "task cohesion" to mediate the relationship between psychological power distance and the team's effectiveness (Hypothesis 1); and the feeling of social acceptance to mediate the relationship between psychological power distances and "task cohesion" (Hypothesis 2).

\section{Method \\ Participants and Procedure}

Eighty-three students (12 females, 71 males, $M=22$ years, $S D=8$ months) from the same engineering school were put together in teams and participated to the study. Teams were formed around industrial- or R \& D-related projects, over a 30 -week period. After four months of operation, students were asked to fill in a questionnaire presented as meant to identify their team's operating modalities

\section{Measures}

Power distance. Each team member expressed his sense of leadership and power, using five-point scales from seven items $(\alpha=.81)$ referring to the importance of their work for the project, to its contribution to conflict resolution, to the collective success or to communications quality. Individual power distance corresponded to the difference between the team-leader's score and each teammate's (Auzoult \& Abdellaoui, 2011).

Cohesion. "Task cohesion" was measured using five-point scales from 12 items $(\alpha=.78)$ about mutual agreement on objectives (clarity, commitment and agreement), the means implemented to achieve the project (agreement on roles and working methods) or team management (conflicts management, mutually supportive behaviour).

Sense of relatedness. The sense of relatedness was measured using the "feeling of relatedness" scale (Richer \& Vallerand, 1998), while the sub-dimensions of intimacy and acceptance had been separated beforehand.

Work-team's effectiveness. An overall indicator of the team's effectiveness was drawn from three dimensions proposed by Beaudin \& Savoie (1995) to measure work-teams' effectiveness (group life quality, durability and performance). Respondents had to deal with 9 items $(\alpha=.78)$ on five-point scales.

\section{Results}

Reducing distances can be associated with a rise in the degree of acceptance $(r=-.42, p<.001)$ or intimacy $(r=-.43, p$ $<.001)$ and an increase in "task cohesion" $(r=-.33, p<.01)$ or in perceived effectiveness $(r=-.35, p<.001)$. Enhanced the task cohesion is associated with the team's perceived effectiveness $(r=.73, p<.001)$ as well as with a heightened sense of acceptance $(r=.64, p<.001)$ or of intimacy $(r=.60, p<.001)$.

We conducted a hierarchical linear regression analysis (Table 1) by introducing power distance in the first step, the two sub-dimensions of relatedness in the second one and, in the third step, "task cohesion". The dependent variable was "level of perceived work-team's effectiveness".

Power distance alone can account for $11 \%\left(R^{2}=.11, F(1,82)\right.$ $=11.27, p<.001)$ of the variance related to work-team's effectiveness. In the second step, the addition of two relatedness sub-dimensions can explain $26 \%\left(\Delta R^{2}\right)$ of additional variance $\left(R^{2}=.37, F(3,82)=16.77, p<.001\right)$. In this case, acceptance alone contributes significantly to justify effectiveness. It can
Table 1.

Hierarchical regression analysis of team-effectiveness from its antecedents.

\begin{tabular}{lccc}
\hline & Step 1 & Step 2 & Step 3 \\
\cline { 2 - 4 } & $\beta$ Student'test $^{\mathrm{a}}$ & $\beta$ Student'test & $\beta$ Student'test \\
\hline Power distance & $-.35 t=-3.36^{*}$ & $-.09 t=-.92$ & $-.06 t=-.80$ \\
Acceptation & & $.38 t=2.49^{*}$ & $.13 t=.97$ \\
Intimacy & & $.23 t=1.51$ & $.09 t=.71$ \\
Task cohesion & & & $.57 t=5.90^{* *}$ \\
Constant & $25.49^{* *}$ & $17.72^{* *}$ & $7.82^{*}$ \\
\hline
\end{tabular}

Note: a. ${ }^{*} p<.01, \stackrel{* *}{p}<.001$.

therefore be concluded that power distances account for the sense of relatedness through acceptance but not for intimacy among team members. In the third step, adding "task cohesion" justifies $19 \%\left(\Delta R^{2}\right)$ of additional variance $\left(R^{2}=.56, F(4,82)=\right.$ $26.65, p<.001)$. All these relationships lead one to conclude that "task cohesion" mediates the relationship between psychological power distance and team's effectiveness (Hypothesis 1 is verified) and that acceptance plays a mediating role between power distance and "task cohesion" (Hypothesis 2 is verified).

\section{Discussion}

The results of this study show that the reduction of perceptual power distances between teammates and their team-leader emphasizes "individual feeling of acceptance" within the team, "task cohesion" and "team's perceived effectiveness".

The sense of relatedness proves to be a determinant factor of participation, motivation and individual well-being at work (Deci, Connell \& Ryan, 1989; Gagné \& Deci, 2005). Our results lead to the conclusion that "sense of relatedness" also impacts the collective level, in this case the team's cohesion and effectiveness. This can be paralleled with the effects observed about the need for autonomy and competence in the context of the self-determination theory (Ryan \& Deci, 1999; Chirkov, Ryan, \& Sheldon, 2011). Indeed, Cabrera Collins and Salgado (2006) have observed that "satisfaction of the need for autonomy" led to greater motivation to share knowledge within the work-group. Morrison (2006) noted that "satisfaction of the need for autonomy" was associated with enhanced pro-social behaviour. These different results may suggest that developing intrinsic motivation linked to "needs for autonomy" and "need for relatedness" might be expected to lead to collective regulations along the lines of strengthening ties at work and, incidentally, to collective efficiency as well.

Finally, perceptual power distances are likely to account for the regulations operating within work-teams. Unlike values, perceptual power distances are directly related to organisations' formal aspects, such as "type of hierarchical structure" $(\mathrm{Ng}$, 1980) or unequal power resources (Raven, 1992). Our results therefore suggest possible practical implications, since any formal element reflecting proximity among teammates and their leadership makes it possible to a priori reduce psychological power distances.

\section{REFERENCES}

Abdel-Halim, A. A. (1980). Power equalization and work effectiveness: An empirical investigation. Journal of Occupational Behaviour, 1, 
223-237.

Ashkanasy, N. M., \& O'Connor, C. (1997). Value congruence in leader-member exchange. Journal of Social Psychology, 137, 647662. http://dx.doi.org/10.1080/00224549709595486

Auzoult, L. (2012). How psychological distances from power develop through power distance values. Psihologia Sociala, 29, 7-15.

Auzoult, L., \& Abdellaoui, S. (2011). The mediating role of reflexivity and climate between power distance and efficiency of a working team. Psychologie du Travail et des Organisations, 17, 1-10.

Beaudin, G., \& Savoie, A. (1995). L'efficacité des équipes de travail: Définition, composantes et mesures. Revue Québécoise de Psychologie, 16, 185-201.

Cabrera, A, Collins, W. C, \& Salgado, J. F. (2006). Determinants of individual engagement in knowledge sharing. The International Journal of Human Resources Management, 17, 245-264. http://dx.doi.org/10.1080/09585190500404614

Campion, A. C., Papper, E. M., \& Medsker, G. J. (1996). Relations between work team characteristics and effectiveness: A replication and extension. Personnel Psychology, 49, 429-452. http://dx.doi.org/10.1111/j.1744-6570.1996.tb01806.x

Chirkov, V. I., Ryan, R. M., \& Sheldon, K. M. (2011). Human autonomy in cross-cultural context, perspectives on the psychology of agency, freedom and well-being. London: Springer. http://dx.doi.org/10.1007/978-90-481-9667-8

Cohen, S. G., \& Bailey, D. E. (1997). What makes teams work: Group effectiveness research from the shop floor to the executive suite. Journal of Management, 23, 239-290. http://dx.doi.org/10.1177/014920639702300303

Deci, E. L., Connell, J. P., \& Ryan, R. M. (1989). Self-determination in a work organization. Journal of Applied Psychology, 74, 580-590. http://dx.doi.org/10.1037/00219010.74.4.580

Dierdorff, E. C., Bell, S. T., \& Belohlav, J. A. (2011). The power of "we": Effects of psychological collectivism on team performance over time. Journal of applied psychology, 96, 247-262. http://dx.doi.org/10.1037/a0020929

Earley, P. C. (1999). Playing follow the leader: Status-determining traits in relation to collective efficacy across cultures. Organizational Behavior and Human Decision Processes, 80, 192-212. http://dx.doi.org/10.1006/obhd.1999.2863

Evans, C. R., \& Dion, K. L. (1991). Group cohesion and performance: A meta-analysis. Small Group Research, 22, 175-186. http://dx.doi.org/10.1177/1046496491222002

Festinger, L. (1950). Informational social communication. Psychological Review, 57, 271-284. http://dx.doi.org/10.1037/h0056932

Friedkin, N. E. (2004). Social cohesion. Annual Review of Sociology, 30, 409-425. http://dx.doi.org/10.1146/annurev.soc.30.012703.110625

Gagné, M., \& Deci, E. L. (2005). Self-determination theory as a new framework for understanding organizational behavior. Journal of Organizational Behavior, 26, 331-362. http://dx.doi.org/10.1002/job.322

Gladstein, D. L. (1984). Groups in context: A model of task group effectiveness. Administration Science Quarterly, 29, 499-517. http://dx.doi.org/10.2307/2392936
Hofstede, G. (2001). Culture's consequences-Comparing values, behaviors, institutions and organizations across nations. Thousand Oaks, CA: Sage publications.

Hsu, M. H., Chen, Y.-L., I., Chiu, C. M., \& Ju, T. L. (2007). Exploring the antecedents of team performance in collaborative learning of computer software. Computers \& Education, 48, 700-718. http://dx.doi.org/10.1016/i.compedu.2005.04.018

Jordan, M. H., Feild, H. S., \& Armenakis, A. (2002). The relationship of group process variables and team performance: A team-level analysis in a field setting. Small Group Research, 33, 121-150. http://dx.doi.org/10.1177/104649640203300104

Lavigne, G. L., Vallerand, R. J., \& Crevier-Braud, L. (2011). The fundamental need to belong on the distinction between growth and deficit-reduction orientations. Personality and Social Psychology Bulletin, 37, 1185-1201. http://dx.doi.org/10.1177/0146167211405995

Lent, R. W., Schmidt, J., \& Schmidt, L., (2006). Collective efficacy beliefs in student work teams: relation to self-efficacy, cohesion, and performance. Journal of Vocational Behavior, 68, 73-84. http://dx.doi.org/10.1016/j.jvb.2005.04.001

Lira, E. M., Ripoll, P., Peiró, J. M., \& González, P. (2007). The roles of group potency and information and communication technologies in the relationship between task conflict and team effectiveness: A longitudinal study. Computers in Human Behavior, 23, 2888-2903. http://dx.doi.org/10.1016/j.chb.2006.06.004

Mesmer-Magnus, J. R., \& De Church, L. A. (2009). Information sharing and team performance: A meta-analysis. Journal of Applied Psychology, 94, 535-546. http://dx.doi.org/10.1037/a0013773

Mulder, M. (1977). The daily power game. Leiden: Martinus Nijhoff. http://dx.doi.org/10.1007/978-1-4684-6951-6

Mullen, B., \& Cooper, C. (1994). The relation between group cohesiveness and performance: An integration. Psychological Bulletin, 115, 210-227. http://dx.doi.org/10.1037/0033-2909.115.2.210

Ng, S. H. (1980). The social psychology of power. London: Academic Press.

Raven, B. H. (1992). A power/interaction model of interpersonal influence. Journal of Social Behavior and Personality, 7, 217-244.

Richer, S. F., \& Vallerand, R. J. (1998). Construction and validation of the need to belong scale. European Review of Applied Psychology, 48, 129-137.

Ryan, R. M., \& Deci, E. L. (1999). Approaching and avoiding selfdetermination: Comparing cybernetic and organismic paradigms of motivation. In R. S. Wyer (Ed.), Perspectives on behavioral selfregulation, Volume 12 (pp. 193-217). Mahwah, NJ: Lawrence Erlbaum Associates.

Schaubroeck, J., Lam, S. S. K., \& Cha, S. E. (2007). Embracing transformational leadership: Team values and the impact of leader behavior on team performance. Journal of Applied Psychology, 92, 1020 1030. http://dx.doi.org/10.1037/0021-9010.92.4.1020

Stinglhamber, F., Bentein, K., \& Vandenberghe, C., (2004). Value congruence and commitment to the organization and to the work group. Psychologie du Travail et des Organisations, 10, 165-187. http://dx.doi.org/10.1016/j.pto.2004.04.008 